\title{
A MUTANT OF SACCHAROMYCES CEREVISIAE TEMPERATURE SENSITIVE FOR FLOCCULATION. INFLUENCE OF OXYGEN AND RESPIRATORY DEFICIENCY ON FLOCCULENCE
}

\author{
by \\ STEEN HOLMBERG and MORTEN C. KIELLAND-BRANDT \\ Department of Physiology, Carlsberg Laboratory, \\ Gamle Carlsberg Vej 10, DK-2500 Copenhagen, Valby
}

Keywords: Yeast genetics, petite, mitochondrial function

\begin{abstract}
A flocculent strain of Saccharomyces cerevisiae, containing the dominant gene for flocculence FL04, was mutagenized with $\mathrm{N}$-methyl- $\mathrm{N}^{\prime}$-nitro- $\mathrm{N}$-nitrosoguanidine. Non-flocculent mutants were isolated with a selection procedure based on the slower sedimentation of non-flocculent cells. One closer studied mutant was due to an unlinked suppressor mutation for FL04. This suppressor gene is designated sufl. The gene sufl is neither centromere linked nor linked to his 4 or the mating type locus. The gene sufl behaves as a recessive in some diploids and as a dominant in others, illustrating the genetic complexity of the flocculation phenomenon.

The mutant was found to be non-flocculent after growth at $30^{\circ} \mathrm{C}$ whether aerated or not. At $22^{\circ} \mathrm{C}$ the mutant was flocculent in the absence of aeration during growth, but non-flocculent with aeration or supplementation of the growth medium with ergosterol and unsaturated fatty acids. None of several inhibitors of mitochondrial functions had any effect on the expression of flocculence. A number of petites induced in the mutant strain with ethidium bromide had altered flocculation phenotypes.
\end{abstract}

A method for measuring flocculence using the spectrophotometer is described.

\section{INTRODUCTION}

Yeast flocculation is characterized by reversible clumping of cells and rapid sedimentation of the clumps from the medium. It is promoted by the presence of divalent metal ions, especially calcium (11). The flocculation charac- teristics of the yeast used in brewing influence the extent of fermentation and are important for the removal of cells from the fermented wort. Different gene loci which determine flocculence have been identified in strains of Saccharomyces cerevisiae $(9,14)$. 
A common approach to the study of yeast flocculence has been to compare flocculent and non-flocculent strains with respect to certain biochemical parameters as examplified by the recent papers of MARFEY et al. (10) and JAYATISSA and ROSE (8). The information gained from such comparisons would be greatly enhanced if the strains analyzed were isogenic except for the locus or loci affecting flocculence. Thereby one could exclude the possibility that the biochemical differences observed are due to genetic differences unrelated to flocculence. One way to obtain such a series of isogenic strains is to isolate in one genotype single gene mutants with altered flocculence. Co-segregation of the flocculence characteristics with the biochemical parameter in question can establish close causal relationships between the two.

This paper describes the isolation of nonflocculent mutants from a flocculent strain of $S$. cerevisiae as well as a genetic analysis of one of the mutants. Some experiments on the influence of different growth conditions and respiratory deficiency on the flocculence of the mutant are presented.

\section{MATERIALS AND METHODS}

\subsection{Media}

YPD consists of yeast extract (Difco) $10 \mathrm{~g} / 1$, Bacto peptone (Difco) $20 \mathrm{~g} / \mathrm{l}$, and glucose, $20 \mathrm{~g}$ / 1. YPG is the same as YPD, except that it contains $20 \mathrm{~g} / 1$ of glycerol instead of glucose. Media for the detection of nutritional requirements were minimal media appropriately supplemented with nutrients as described by ZimMERMANN (15). Antimycin, oligomycin, ethidium bromide, tetracycline, and erythromycin were obtained from Sigma. Ergosterol was from British Drug House and Tween 80 was from Bie and Berntsen (Copenhagen).

Media were solidified with agar (Difco) $20 \mathrm{~g} /$ I.

\subsection{Strains and crosses}

Strains used are shown in Table I. Crosses and tetrad analysis were carried out according to HAWTHORNE and MORTIMER (6). It was in all cases checked that nutritional characters segregated as expected. The segregation of mating type was determined whenever all four clones in a tetrad were auxotrophic.

\subsection{Measurement of flocculence}

Spectrophotometric determination of flocculence was done as follows: The yeast was grown for two or three days in YPD under the conditions specified. The culture was shaken on a whirlimixer to make the suspension uniform and $1.7 \mathrm{ml}$ were placed in a $3 \mathrm{ml}$ cuvette in a Zeiss PMQ 3 spectrophotometer equipped with a Servogor $\mathrm{Sb}$ recorder. The decrease in extinction at $660 \mathrm{~nm}$ was recorded during 3 minutes and the maximal rate of decrease determined graphically from the slope of the curve. The rate is used as a measure of flocculence.

In most of the genetic analyses a less time consuming visual method was used: A small inoculum of the yeast strain was seeded into a culture tube containing $10 \mathrm{ml}$ of YPD. After 3 days of growth without shaking at $30^{\circ} \mathrm{C}$ or $22^{\circ} \mathrm{C}$, the tube was shaken and the rapidity of floc formation as well as floc size evaluated by eye. The results of this test are expressed on a subjective scale ranging from 0 to $5 ; 0$ means non-flocculent, 5 means extremely flocculent.

\subsection{Mutagenesis}

Cells were grown with aeration for more than 5 generations in a medium consisting of yeast extract $(10 \mathrm{~g} / 1)$, Bacto peptone $(10 \mathrm{~g} / 1)$, and glucose $(30 \mathrm{~g} / 1)$. They were harvested at a turbidity (extinction) of 1.0 at $660 \mathrm{~nm}$. Turbidity was measured half a minute after adding EDTA (final concentration $0.01 \mathrm{M}$ ) to a three times

Abbreviations: $F=$ flocculent phenotype, $N F=$ non-flocculent phenotype, $P D=$ parental ditype, $T T=$ tetratype, $\mathrm{NPD}=$ non-parental ditype, $\mathrm{ND}=$ not determined, $\mathrm{YPD}=$ Yeast extract Peptone Dextrose, $\mathrm{YPG}=$ Yeast extract Peptone Glycerol. 


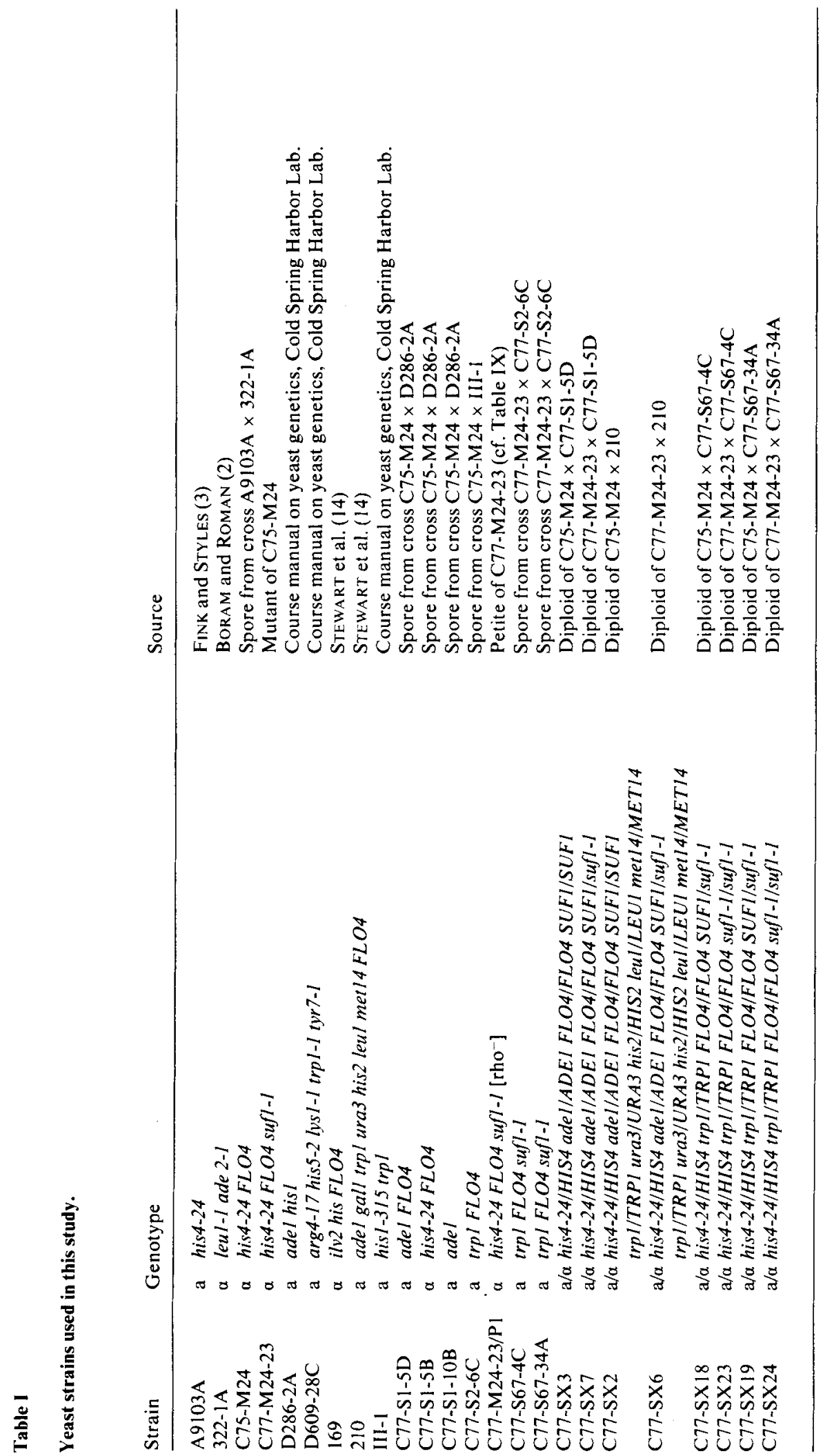


diluted sample of the culture in order to counteract flocculence by removing calcium ions. Cells were washed with $0.1 \mathrm{M}$-sodium maleate, $0.003 \mathrm{M}$-EDTA, pH 6.5 and suspended in the same medium at $5 \times 10^{8} \mathrm{cells} / \mathrm{ml}$. N-methyl-N'nitro- $\mathrm{N}$-nitrosoguanidine was added to a final concentration of $0.7 \mu \mathrm{M}$ and the cell suspension was incubated with shaking at $30^{\circ} \mathrm{C}$. To obtain a survival of $1 \%$, incubation was continued for 65 minutes, during which period survival decreased exponentially. Cells were subjected to selection after washing in water. Mutagen waste was inactivated with alkaline potassium permanganate.

\subsection{Selection for non-flocculent mutants}

After mutagenesis the cells were transferred to $10 \mathrm{ml}$ of YPD and incubated with shaking at $30^{\circ} \mathrm{C}$. After 48 hours the tubes were placed vertically and the yeast cells allowed to sediment. After 4 hours $2 \mathrm{ml}$ from the upper part of the sedimenting cell mass were transferred to a new tube containing $8 \mathrm{ml}$ of YPG in order to exclude petites. After 24 hours, $8 \mathrm{ml}$ of YPD were added to permit flocculation and the cultures incubated for additional 24 hours with shaking at $30^{\circ} \mathrm{C}$. This cycle of sedimentation, growth on YPG followed by growth on YPD was repeated 12 times. After selection cells were plated at low cell density. Isolated colonies were then tested for flocculence.

\subsection{Petite induction}

Cells grown overnight were added to the following medium: Succinic acid $(10 \mathrm{~g} / 1)$, sodium hydroxide $(6 \mathrm{~g} / 1)$, yeast extract $(5 \mathrm{~g} / 1)$, Bacto peptone $(10 \mathrm{~g} / 1)$, yeast nitrogen base (Difco) $6.7 \mathrm{~g} / 1$, glucose $(20 \mathrm{~g} / 1)$, and ethidium bromide $(50 \mathrm{mg} / 1)$. The cells were grown for 5 hours or for 3 days and plated on YPD. Isolated colonies were picked and tested for growth on YPG.

\section{RESULTS}

\subsection{Measurement of flocculation}

Flocculence was determined either spectrophotometrically or visually. The

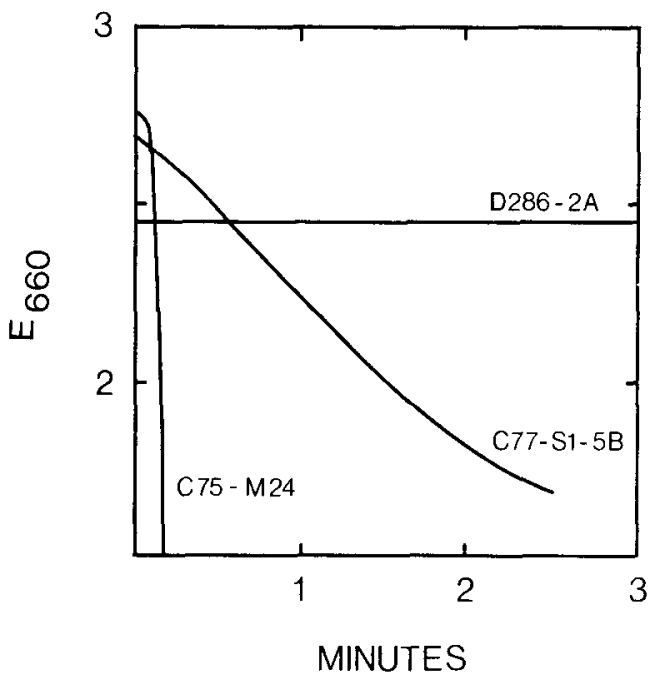

Figure 1. Spectrophotometer recordings of three strains differing in flocculence. A uniform suspension of the yeast was placed in the cuvette and the extinction at $660 \mathrm{~nm}$ recorded. The maximal rate of decrease of extinction is for the extremely flocculent strain C75-M24 3.6 extinction units $\times \mathrm{min}^{-1}$, for the non-flocculent strain D286-2A 0.00 extinction units $x$ $\min ^{-1}$ and for the moderately flocculent strain $\mathrm{C} 77$ S1-5B 0.5 extinction units $\times \mathrm{min}^{-1}$. The 3 strains were grown without shaking at $30^{\circ} \mathrm{C}$ for 3 days.

spectrophotometric method was used to obtain an objective determination. Recordings obtained when measuring flocculation with the spectrophotometer are shown in Fig. 1. The method was found to distinguish well the different degrees of flocculence. Thus, strain C75M24 is extremely flocculent and graded 5 by the visual method, C77-S1-5B is intermediate and graded 3, whereas D286-2A is nonflocculent and graded 0 (Fig. 1).

The method was found to be practically independent of cell density as long as the $E_{660}$ of the undiluted sample is kept between 1 and 3 .

\subsection{Identification of FLO4 in strain C75-M24}

Strain 169 owes its flocculence to the presence of the dominant gene FLO4 on chromosome I (14). The flocculence of C75M24 was found to be dependent on the presence of calcium ions (data not shown) as is that of 169. To find out if the flocculence of C75-M24 is also due to the presence of FLO4, 
the following crosses were carried out. First, it was determined if the flocculence of C75-M24 segregated as a single mendelian character when compared to a non-flocculent laboratory strain. C75-M24 was crossed to D286-2A and 29 asci from the resulting flocculent diploid strain were analyzed. It was found that all asci segregated 2:2 for flocculence vs. nonflocculence, i.e. the difference is determined by a single gene. However, both within and among asci the degree of flocculence of the segregants varied, indicating the existence of several modifying genes. Flocculence and adenine requirement segregated with a PD:TT:NPD ratio of 7:21:1 indicating linkage between adel and the gene determining flocculence (significance at the $5 \%$ level). The three curves in Fig. 1 are representative for the two parents (highly flocculent and non-flocculent) and for a moderately flocculent progeny strain. Since C75-M24 and 169 both are of mating type $\alpha$, we had to use C77-S1-5D (Table I) for the cross to 169. The 24 asci analyzed all segregated $4: 0$ for flocculence. Thus, by the criterion of absence of recombination, the gene in C75-M24 determining flocculence is identical with or allelic to the FLO4 gene.

\subsection{Isolation of the non-flocculent mutant C77- M24-23}

Several non-flocculent mutants were isolated from C75-M24 after nitrosoguanidine treatment at survival levels of $1 \%$ and $10 \%$. Mutant C77-M24-23 was isolated after mutagenesis to a survival of $1 \%$ and is identical to C75-M24 in mating type, histidine requirement, and growth on YPG. It has no extra nutritional requirements.

\subsection{Genetic characterization of strain C77-M24- 23}

The flocculation properties of C77-M24-23 were found to be temperature dependent if the cultures were grown without shaking; it was non-flocculent after growth at $30^{\circ} \mathrm{C}$, but flocculent after growth at $22^{\circ} \mathrm{C}$ (Fig. 2). The flocculence of C77-M24-23 at $22^{\circ} \mathrm{C}$ could be eliminated with EDTA like that of C75-M24.

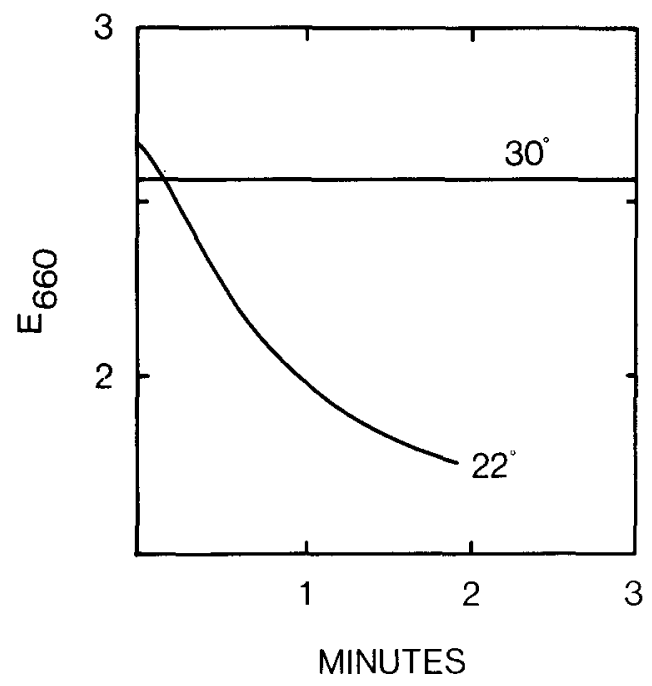

Figure 2. Effect of growth temperature on the flocculence of the mutant C77-M24-23 grown without shaking for 3 days. At $22^{\circ} \mathrm{C}$ the maximal rate of the decrease in extinction is 0.6 units $\times \mathrm{min}^{-1}$, whereas at $30^{\circ} \mathrm{C}$ the rate is 0.00 units $\times \mathrm{min}^{-1}$.

To find out if C77-M24-23 had mutated in the FLO4 locus, it was crossed to the non-flocculent strain $\mathrm{C} 77-\mathrm{S} 1-10 \mathrm{~B}$. The spore cultures from 11 asci were tested for flocculence at $22^{\circ} \mathrm{C}$ and $30^{\circ} \mathrm{C}$ (Table II). All asci segregated $2: 2$ when tested at $22^{\circ} \mathrm{C}$, as might be expected, since $\mathrm{C} 77$ M24-23 is flocculent at this temperature. No asci showed 0:4 segregation for flocculence/ non-flocculence at $30^{\circ} \mathrm{C}$. This demonstrates that the mutation in C77-M24-23 is not located in FLO4 but has occurred elsewhere in the genome. To test if the change in C77-M24-23

\section{Table II}

Tetrad analysis of C77-M24-23 (a his4) NF × C77S1-10B (a adel) NF.

\begin{tabular}{l|c|c}
\hline Character & \multicolumn{2}{|c}{ Number of asci segregating } \\
& $2: 2$ & $1: 3$ \\
\hline $\mathrm{F} / \mathrm{NF}$ at $22^{\circ} \mathrm{C}$ & 11 & 0 \\
$\mathrm{~F} / \mathrm{NF}$ at $30^{\circ} \mathrm{C}$ & 6 & 5 \\
$\mathrm{a} / \mathrm{a}$ & $5 \mathrm{a}$ & 0 \\
his $/ H I S$ & 11 & 0 \\
ade/ADE & 11 & 0 \\
\hline
\end{tabular}

a) Only 5 asci were completely analyzed for mating type (cf. Materials and Methods). 


\section{Table III}

Tetrad analysis of C77-M24-23 (a his4 FLO4) NF $\times$ C77-S2-6C (a trpl FLO4) F at 30 ${ }^{\circ} \mathrm{C}$.

Number of tetrads analyzed was 21 . All asci segregated $2: 2$ for flocculence.

\begin{tabular}{l|c|c|r}
\hline Characters & \multicolumn{3}{|c}{ Number of asci } \\
& PD & NPD & TT \\
\hline trp/TRP, NF/F & 3 & 6 & 12 \\
his/HIS, NF/F & 6 & 2 & 13 \\
$\mathrm{a} / \mathrm{\alpha}^{\mathrm{a}}, \mathrm{NF} / \mathrm{F}$ & 2 & 5 & 4 \\
\hline
\end{tabular}

a) Only 11 asci were completely analyzed for mating type (cf. Materials and Methods).

causing non-flocculence at $30^{\circ} \mathrm{C}$ represents a single gene mutation, the strain was crossed to C77-S2-6C, which also carries FL04 (cf. Table I). The analysis of 21 asci is given in Table 111 . Flocculence at $30^{\circ} \mathrm{C}$ segregated $2: 2$ in all cases, showing that a mutation in one locus causes non-flocculence at $30^{\circ} \mathrm{C}$. We call this locus sufl (for suppressor of FLO4) and the mutation sufll. The wild type allele is correspondingly SUFl. The cross also gives information concerning linkage. The ratios of PD:NPD for the three marker pairs amounting to 3:6 (sufl-trpl), 6:2 (sufl - his 4 ) and $2: 5$ (sufl $-\alpha$ ) reveal no significant linkage (12) between sufl and these markers. The high frequency of tetratypes in the combination with the closely (6) centromere linked trpl (less than 1\%) shows sufl not to be closely linked to the centromere of its chromosome. An additional cross to a different strain carrying FLO4 as described under 3.6. confirmed the $2: 2$ segregation of suff.

The sufl haploid segregants from the cross C77-M24-23 x C77-S2-6C were identified by non-flocculence at $30^{\circ} \mathrm{C}$. When these were tested for flocculence at $22^{\circ} \mathrm{C}$ unexpectedly about $40 \%$ of these segregants were nonflocculent also at this temperature. This shows that in certain genetic backgrounds $22^{\circ} \mathrm{C}$ can no longer be considered as a permissive temperature for sufl.

Similarly, influences of the genetic background were encountered in an experiment designed to determine whether sufl is dominant or recessive (Table IV). Several pairs of isogenic diploid strains differing at the sufl locus were tested for flocculence at $30^{\circ} \mathrm{C}$. In the first pair (Table IV) the sufl allele is dominant over the $S U F I$ allele. In the second pair the sufl allele is only weakly expressed in the presence of the $S U F /$ allele. In the last two pairs of Table IV the heterozygote is compared to the sufl homozygote. In this comparison sufl appears recessive. However, the homozygous sufl diploid C77-SX23 is weakly flocculent after growth at $30^{\circ} \mathrm{C}$. Whether this unexpected behaviour of the diploid is due to a genetic background modifying the temperature sensitivity will have to be tested on haploid progenies of this strain.

\subsection{Influence of growth conditions}

The temperature effect on the flocculence of C77-M24-23 is only expressed when it is grown without shaking. To determine if this is caused by the absence of oxygen, C77-M24-23 was grown with or without shaking, in the presence or absence of oxygen at $22^{\circ} \mathrm{C}$. C75-M24 and 169 were included for comparison. Table $\mathrm{V}$ shows that anaerobiosis during growth at $22^{\circ} \mathrm{C}$ causes C77-M24-23 to flocculate, whether the culture is shaken or not.

When yeast cells are grown in the absence of oxygen a nutritional requirement is induced for sterols and unsaturated fatty acids (1). If the effect of anaerobiosis on flocculation is due to starvation for these lipids, supplementation of the growth medium should neutralize the effect. Therefore C75-M24, C77-M24-23, and 169 were grown anaerobically with or without a supplement of ergosterol and unsaturated fatty acids and tested for flocculence. The lipid supplementation indeed counteracts the effect of anaerobic conditions (Table VI). Interestingly, the strain 169 gives with regard to flocculation a response to temperature, anaerobiosis, and the lipids somewhat similar to that of C77-M24-23. C75-M24 and the non-flocculent D609-28C are not affected by anaerobic growth conditions or lipid supplementation. An addition of the lipids just before measurement had no effect (data not shown). The experiments of Table VI indicate that absence of oxidative phosphorylation is not the reason for flocculence under anaerobic conditions. The 
Table IV

Flocculence of isogenic pairs of diploid strains differing at the sufl locus.

\begin{tabular}{|c|c|c|c|}
\hline \multirow[t]{2}{*}{ Isogenic pairs } & \multirow[t]{2}{*}{ Origin } & \multirow[t]{2}{*}{ Relevant markers } & \multirow{2}{*}{$\begin{array}{l}\begin{array}{l}\text { Flocculation after } \\
\text { growth at } 30^{\circ} \mathrm{C}\end{array} \\
\text { Visual evaluation scale } \\
\text { O(NF) }-5(\mathrm{~F})\end{array}$} \\
\hline & & & \\
\hline C77-SX2 & $\mathrm{C} 75-\mathrm{M} 24 \times 210$ & FLO4/FLO4 SUFI/SUFI & 3 \\
\hline$-S \times 6$ & $\mathrm{C} 77-\mathrm{M} 24-23 \times 210$ & FLO4/FLO4 sufl/SUFI & 0 \\
\hline $\mathrm{C} 77-\mathrm{S} X 3$ & $\mathrm{C} 75-\mathrm{M} 24 \times \mathrm{C} 77-\mathrm{S} 1-5 \mathrm{D}$ & FLO4/FLO4 SUFI/SUFI & 4 \\
\hline$-\mathrm{SX7}$ & C77-M24-23 × C77-S1-5D & FLO4/FLO4 sufl/SUFI & 3 \\
\hline $\mathrm{C} 77-\mathrm{S} X 18$ & C75-M24 × C77-S67-4C & FLO4/FLO4 sufI/SUFI & 5 \\
\hline$-S \times 23$ & $\mathrm{C} 77-\mathrm{M} 24-23 \times \mathrm{C} 77-\mathrm{S} 67-4 \mathrm{C}$ & FLO4/FLO4 sufl/sufl & 2 \\
\hline C77-SX19 & C75-M24 × C77-S67-34A & FLO4/FLO4 sufl/SUFI & 3 \\
\hline$-\mathrm{S} \times 24$ & $\mathrm{C} 77-\mathrm{M} 24-23 \times \mathrm{C} 77-\mathrm{S} 67-34 \mathrm{~A}$ & FLO4/FLO4 sufI/sufI & 0 \\
\hline
\end{tabular}

Table V

Effect of anaerobiosis during growth at $22^{\circ} \mathrm{C}$ on flocculence. Aerobic conditions without shaking were achieved by growing the cells in $100 \mathrm{ml}$ of YPD in a 31 flask and gently blowing air saturated with water over the surface of the culture. Anaerobic conditions with shaking were achieved by bubbling the medium with nitrogen throughout the incubation period.

\begin{tabular}{l|cccc}
\hline Strain & Stationary anaerobic & Stationary aerobic & Shaking anaerobic & Shaking aerobic \\
\hline C75-M24 & F & F & F & F \\
C77-M24-23 & F & NF & F & NF \\
169 & F & F & ND & ND \\
\hline
\end{tabular}

Table VI

Ergosterol and Tween 80 counteract anaerobiosis.

\begin{tabular}{l|c|c|c}
\hline Strain & \multicolumn{2}{|c}{$\begin{array}{c}\text { Flocculence determined spectrophotometrically (extinction units } \times \text { min-1) } \\
\text { Anaerobiosis }\end{array}$} \\
& $\begin{array}{c}\text { Anaerobiosis } \\
\text { Without lipids }\end{array}$ & $\begin{array}{c}\text { With ergosterol }(20 \mathrm{mg} / 1) \\
\text { and Tween } 80(5 \mathrm{~g} / 1)\end{array}$ & $\begin{array}{c}\text { Aerobiosis } \\
\text { Without lipids }\end{array}$ \\
\hline $\mathrm{C} 75-\mathrm{M} 24$ at $22^{\circ} \mathrm{C}$ & 1.9 & 2.0 & 3.0 \\
$\mathrm{C} 77-\mathrm{M} 24-23$ at $22^{\circ} \mathrm{C}$ & 0.23 & 0.00 & 0.00 \\
$\mathrm{C} 77-\mathrm{M} 24-23$ at $30^{\circ} \mathrm{C}$ & 0.00 & $\mathrm{ND}$ & 0.00 \\
169 at $22^{\circ} \mathrm{C}$ & 0.14 & 0.03 & 0.01 \\
169 at $30^{\circ} \mathrm{C}$ & 0.12 & 0.00 & 0.00 \\
$\mathrm{D} 609-28 \mathrm{C}$ at $22^{\circ} \mathrm{C}$ & 0.00 & 0.00 & 0.00 \\
$\mathrm{C} 77-\mathrm{M} 24-23 / \mathrm{Pl}$ at $22^{\circ} \mathrm{C}$ & 1.35 & 6.0 & $\mathrm{~F}$ \\
& & & \\
\hline
\end{tabular}


Table VII

Flocculence after growth in the presence of inhibitors of different mitochondrial functions. Growth took place at $22^{\circ} \mathrm{C}$ with shaking for 72 hours. Flocculence was determined visually, scale $0(N F) \cdot 5(F)$.

\begin{tabular}{|c|c|c|c|}
\hline Inhibitor added & $\begin{array}{l}\text { C75- } \\
\text { M24 }\end{array}$ & $\begin{array}{c}\text { C77- } \\
\text { M24-23 }\end{array}$ & 169 \\
\hline None & 5 & 0 & 1 \\
\hline Antimycin $(0.6 \mu \mathrm{g} / \mathrm{ml})$ & 5 & 0 & $0-1$ \\
\hline Oligomycin $(45 \mu \mathrm{g} / \mathrm{ml})$ & 5 & 0 & 1 \\
\hline Ethidium bromide $(10 \mu \mathrm{g} / \mathrm{ml})$ & 5 & 0 & ND \\
\hline Tetracycline $(0.4 \mathrm{mg} / \mathrm{ml})$ & 5 & 0 & ND \\
\hline Potassium cyanide $(15 \mathrm{~mm})$ & 5 & 0 & ND \\
\hline 2,4-dinitrophenol (2 mM) & 5 & 0 & $0-1$ \\
\hline Erythromycin (2 mg/ml) & 5 & 0 & $0-1$ \\
\hline
\end{tabular}

conclusion is supported by the result obtained with the petite strain C77-M24-23/P1. This respiratory deficient derivative of C77-M24-23 is flocculent under all tested conditions (Table VI). Different inhibitors of mitochondrial functions were used to substantiate for strains C75-M24, C77-M24-23 and 169 that oxidative phosphorylation and mitochondrial protein synthesis are unimportant for the expression of flocculation characteristics (Table VII). As a control for the efficiency of the inhibitors the strains were inocculated in YPG medium containing the inhibitors. No growth was observed in these controls.

STEWART et al. (14) found increased flocculence of strain 169 after growth on maltose compared to glucose and suggested that this is due to decreased catabolite repression of respiration. Therefore we tested the influence on flocculation of replacing glucose with the non-fermentable carbon sources glycerol, sodium lactate, and ethanol. Table VIII shows the result of this experiment on C75-M24, C77-M24-23, and 169 grown at $22^{\circ} \mathrm{C}$ and $30^{\circ} \mathrm{C}$ with shaking (Table VIII). There was no flocculence after growth on the three non-fermentable carbon sources. The flocculence of 169 was in our experiment not affected by replacing glucose with maltose.

An attempt was made to follow the kinetics of inducing flocciulence by a shift experiment. Strain C77-M24-23 was grown aerobically on YPD at $22^{\circ} \mathrm{C}$ and when the culture had reached a turbidity of $E_{660}=0.1$ we shifted to nitrogen bubbling. Samples were withdrawn and concentrated by centrifugation followed by suspension of the cells in fresh medium to give a turbidity of 1.5. It took more than 6 hours before the culture began to show flocculence. Possibly, enough of the essential lipids were present in the cells during this period to prevent the development of flocculence.

\subsection{Flocculence of petites}

The petite condition has been reported to affect flocculence (13). Petites of C75-M24, C77M24-23, and 169 were induced with ethidium bromide (cf. Materials and Methods). They were classified into groups according to

\section{Table VIII}

Flocculence after growth on different carbon sources. Growth took place with shaking for 72 hours. The medium was identical to YPD except that glucose was omitted when the indicated other carbon sources were present at $2 \%$.

\begin{tabular}{|c|c|c|c|c|c|c|}
\hline \multirow[t]{3}{*}{ Carbon source } & \multicolumn{6}{|c|}{ Flocculence determined spectrophotometrically (extinction units $\times \min ^{-1}$ ) } \\
\hline & \multicolumn{2}{|c|}{$\mathrm{C} 75-\mathrm{M} 24$} & \multicolumn{2}{|c|}{$\mathrm{C} 77-\mathrm{M} 24-23$} & \multicolumn{2}{|c|}{169} \\
\hline & $30^{\circ} \mathrm{C}$ & $22^{\circ} \mathrm{C}$ & $30^{\circ} \mathrm{C}$ & $22^{\circ} \mathrm{C}$ & $30^{\circ} \mathrm{C}$ & $22^{\circ} \mathrm{C}$ \\
\hline $\begin{array}{l}\text { Non-fermentable carbon } \\
\text { sources: glycerol, sodium }\end{array}$ & & & & & & \\
\hline lactate or ethanol & 0.00 & 0.00 & 0.00 & 0.00 & 0.00 & 0.00 \\
\hline Glucose & 2.8 & 7.5 & 0.00 & 0.00 & 0.005 & 0.01 \\
\hline Maltose & ND & ND & ND & ND & 0.005 & 0.01 \\
\hline
\end{tabular}


Table IX

Floceulence of ethidium bromide induced petites. Growth took place with shaking for 72 hours.

\begin{tabular}{l|c|c|c}
\hline $\begin{array}{l}\text { Flocculence determined } \\
\text { with the spectrophotometer }\end{array}$ & C75-M24 at $30^{\circ} \mathrm{C}$ & $\begin{array}{c}\text { Number of petites analyzed from } \\
\text { and } 30^{\circ} \mathrm{C}\end{array}$ & 169 at $30^{\circ} \mathrm{C}$ \\
\hline $\begin{array}{l}\text { Unchanged flocculence } \\
\text { Reduced flocculence }\end{array}$ & 5 & 2 & 0 \\
No flocculence (rate=0.00 & 32 & 0 & 5 \\
extinction units $\times$ min-1) & 3 & 38 & 39 \\
Increased flocculence & 0 & $1 a$ & 0 \\
\hline Total tested & 40 & 41 & 44 \\
\hline
\end{tabular}

a) Flocculent both at $22^{\circ} \mathrm{C}$ and $30^{\circ} \mathrm{C}$. This particular petite $(\mathrm{C} 77-\mathrm{M} 24-23 / \mathrm{PI})$ was isolated after growth in minimal medium (15) with $10 \mu \mathrm{g} / \mathrm{ml}$ ethidium bromide for 5 days. Survival was less than $1 \%$ after this treatment.

flocculence (Table IX). In most cases petites had unchanged, reduced, or no flocculence compared to their parent strain, but one petite of C77-M24-23 showed increased flocculence in that it was flocculent at $30^{\circ} \mathrm{C}$. This petite, C77-M24-23/P1 was crossed to C77-S1-5D, which is SUFI FLO4. Six out of six asci showed 2:2 segregation for flocculence at $30^{\circ} \mathrm{C}$, demonstrating $\left(\mathrm{p}=2 \times 10^{-9}\right)$ that the flocculence of $\mathrm{C} 77-\mathrm{M} 24-23 / \mathrm{Pl}$ at $30^{\circ} \mathrm{C}$ is not due to a new nuclear mutation epistatic to sufl-1.

These results indicate that some mitochondrial functions other than oxidative phosphorylation and protein synthesis are involved in the expression of flocculence, and that some petites can carry out such functions.

\section{DISCUSSION}

\subsection{Measuring flocculence}

Our method of measuring flocculence using the spectrophotometer with automatic recording is fast and easy to perform. Contrary to other quantitative methods $(4,7)$ it is done in the growth medium. Perhaps the most important property of the method is that it makes it possible to clearly distinguish the moderately flocculent strains; this can be done without any normalization according to cell mass.

\subsection{Genetics}

STEWART et al. (14) identified a locus FLO4 on chromosome I determining flocculence. In the present study a suppressor gene for FLO4, $s u f l$, at a different location has been identified.

Clearly, this study reveals genes besides FLO4 and sufl that can modify the degree of flocculence. The genetic determination of flocculence versus non-flocculence of the haploid strains at $30^{\circ} \mathrm{C}$ is, however, adequately explained by differences in these two loci, if a normal mitochondrial genome is present as well as other components of the genotype that could be mutated with ethidium bromide. The fact that C75-M24 and 169 have quantitatively different flocculation phenotypes may well be due to differences in the genetic background. Since the cross between the flocculating strain C77S1-5D and 169 (FLO4) yielded only flocculent progeny, C75-M24 (one parent of C77-S1-5D) must carry FLO4 and not another gene determining flocculence. As is the case for FLO4 (14), the gene in C75-M24 determining flocculence showed linkage to adel. The possibility that 169 and C75-M24 carry two different alleles of the FLO4 gene is, however, not ruled out, but both alleles are dominant.

The non-flocculent mutant C77-M24-23 was obtained after mutagenesis to a survival of $1 \%$. At such a high mutagen dose the probability of more than one hit is high. With respect to 
flocculence versus non-flocculence, the data presented in Table III show that mutation in a single gene is responsible. If, however, one wants to correlate biochemical differences between C75-M24 and C77-M24-23 with the expression of flocculence, then the combined segregation of the biochemical parameter in question and the flocculation phenotype should be investigated in a meiotic analysis. This approach will eliminate the influence of possible other mutational events.

\subsection{Influence of growth conditions and respira- tory deficiency}

The results presented in Tables $\mathrm{V}$ and $\mathrm{VI}$ show that the absence of oxygen and the depletion for sterols and unsaturated fatty acids both induce C77-M24-23 and 169 to flocculate. The fact that a strain exists (C75-M24) in which flocculation is not prevented by addition of the lipids (Table VI), indicates that these do not act as surfactants. This conclusion is supported by the fact that the lipids have to be present during growth to be effective in preventing flocculation. It is likely that strains carrying sufl and strain 169 are under anaerobic conditions deficient for functions which are needed to prevent flocculence, but which can be restored upon supply of the above lipids. Conversely, the fact that starvation for these lipids does not induce flocculence in a non-flocculating strain like D609-28C (Table VI) indicates that flocculation is not simply due to a deficiency of lipids in the cell wall.

Mutation to respiratory deficiency (the petite condition) has been reported to affect the flocculence of Saccharomyces carlsbergensis strains $(5,13)$. It has also been reported that petites of the S. cerevisiae strain 169 are nonflocculent (14). We have found that different petites induced with ethidium bromide in the same strain can have different flocculation phenotypes. This has been established with petites from several strains including 169 (Table IX). An obvious concern in the evaluation of such experiments is whether genetic changes have taken place only in the mitochondrial DNA. This is especially so for the petite of C77M24-23 showing intensified flocculence. Since it was induced under conditions giving low survival, a rare event such as a nuclear mutation could have been selected. The possibility that the intensified flocculence of this petite is caused by a nuclear mutation was ruled out by tetrad analysis. Further characterization of the differences between the petites is needed and such studies are in progress.

Taken together, our results indicate that some mitochondrial functions other than oxidative phosphorylation and protein synthesis are involved in the expression of flocculence, and that some petites can carry out these functions. This is somewhat unexpected and we do not at present wish to propose any hypothesis concerning what kind of function could be involved.

\section{ACKNOWLEDGEMENTS}

We wish to thank Dr. T. NilsSON-TILLGREN, cand.polyt. J. G. Litske PETERSEN, and stud.scient. B. E. ChristensEN for advice and fruitful discussions, Professor D. vON WETTSTEIN for support and encouragement, and Dipl.Biol. B. WILKEN for excellent technical assistance. Thanks are also due to Dr. G. G. STEWART for supplying the strains 169 and 210 .

\section{REFERENCES}

1. Andreasen, A. A. \& T. J. B. Stier: Anaerobic nutrition of Saccharomyces cerevisiae $\mathrm{I}$. Ergosterol requirement for growth in a defined medium. J. Cell. Comp. Physiol. 41, 23-36 (1953)

2. Boram, W. R. \& H. Roman: Recombination in Saccharomyces cerevisiae: A DNA repair mutation associated with elevated mitotic gene conversion. Proc. Natl. Acad. Sci. USA 73, 2828-2832 (1976)

3. Fink, G. R. \& C. A. Styles: Gene conversion of deletions in the his 4 region of yeast. Genetics 77 , 231-244 (1974)

4. Greenshields, R. N., J. Yates, P. Sharp \& T. M. C. DAviEs: Studies in tower continuous fermentation. I. Methods for the characterization of flocculent yeasts. J. Inst. Brew. 78, 236-242 (1972)

5. Gyllang, H. \& E. Martinson: Properties of some spontaneous mutants from brewers yeast with increased sedimentation rate. Eur. Brew. Conv. Proc. Congr., Estoril 1971, 265-271 (1972) 
6. Hawthorne, D. C. \& R. K. Mortimer: Chromosome mapping in Saccharomyces: Centromere-linked genes. Genetics 45, 1085-1110(1960)

7. Helm, E., B. Nøhr \& R. S. W. Thorne: The measurement of yeast flocculence and its significance in brewing. Wallerstein Lab. Commun. 16, 315-326 (1956)

8. Jayatissa, P. M. \& A. H. Rose: Role of wall phosphomannan in flocculation of Saccharomyces cerevisiae. J. Gen. Microbiol. 96, 165-174 (1976)

9. LEWIS, C. W., J. R. JohNSTON \& P. A. MARTIN: The genetics of yeast flocculation. J. Inst. B rew. $82,158-160$ (1976)

10. Marfey, P., S. B. Sørensen \& M. Ottesen: Studies on yeast flocculation. Comparison of enzymatic digests of flocculent and non-flocculent cells of Saccharomyces carlsbergensis. Carlsberg Res. Commun. 42, 353-367 (1977)
11. MiLL, P. J.: The nature of interactions between flocculent cells in the flocculation of Saccharomyces cerevisiae. J. Gen. Microbiol. 35, 61-68(1964)

12. Perkins, D. D.: The detection of linkage in tetrad analysis. Genetics 38, 187-197 (1953)

13. Šllhankova, L., J. Śavel \& J. Mostek: Respiratory deficient mutants of bottom brewer's yeast. I. Frequencies and types of mutant in various strains. J. Inst. B rew. 76, 280-288 (1970)

14. Stewart, G. G., I. F. Garrison, T. E. Goring, M. Meleg, P. Pipasts \& I. Russel: Biochemical and genetic studies on yeast flocculation. KemiaKemi (Helsinki) 3, 465-479 (1976)

15. ZimmermanN, F. K.: Detection of genetically active chemicals using various yeast systems. In: Chemical Mutagens. Principles and Methods for their Detection, A. Hollaender ed., Plenum Press. New York - London, Vol. III pp. 209-239 (1973) 